Article

\title{
Preparation of a Flower-Like Immobilized D-Psicose 3-Epimerase with Enhanced Catalytic Performance
}

\author{
Lu Zheng ${ }^{1}$, Yining Sun ${ }^{1}$, Jing Wang ${ }^{2}$, He Huang ${ }^{1}$, Xin Geng ${ }^{1}$, Yi Tong ${ }^{3, *}$ and Zhi Wang ${ }^{1, *}$ \\ 1 Key Laboratory of Molecular Enzymology and Engineering of Ministry of Education, College of Life Science, \\ Jilin University, Changchun 130012, China; zhengl14@mails.jlu.edu.cn (L.Z.); \\ sunyn1316@mails.jlu.edu.cn (Y.S.); huanghe17@mails.jlu.edu.cn (H.H.); gengxin@163.com (X.G.) \\ 2 Nutrition \& Health Research Institute, COFCO Corporation, Beijing 102209, China; wang_jing3@cofco.com \\ 3 Jilin COFCO Biochemistry Co., Ltd. (National Engineering Research Center of Corn Deep Processing), \\ Changchun 130033, China \\ * Correspondence: tongyi@cofco.com (Y.T.); wangzhi@jlu.edu.cn (Z.W.); Tel.: +86-431-8588-3188 (Y.T.); \\ +86-431-8518-2281 (Z.W.)
}

Received: 31 July 2018; Accepted: 17 October 2018; Published: 18 October 2018

\begin{abstract}
In this present study, we proposed a smart biomineralization method for creating hybrid organic-inorganic nanoflowers using a $\mathrm{Co}^{2+}$-dependent enzyme (D-psicose 3-epimerase; DPEase) as the organic component and cobalt phosphate as the inorganic component. The prepared nanoflowers have many separated petals that have a nanometer size. Under optimum conditions $\left(60^{\circ} \mathrm{C}\right.$ and $\mathrm{pH}$ of 8.5), the nanoflower can display its maximum activity (36.2 $\mathrm{U} / \mathrm{mg}$ ), which is about 7.2-fold higher than free DPEase. Furthermore, the immobilized DPEase presents enhanced $\mathrm{pH}$ and thermal stabilities. The DPEase-nanoflower maintained about $90 \%$ of its activity after six reaction cycles, highlighting its excellent reusability.
\end{abstract}

Keywords: nanoflower; immobilization; metal-dependent enzyme; D-psicose; DPEase

\section{Introduction}

As a rare sugar, D-psicose has attracted much attention for its special nutritional functions [1,2]. It is a helpful sucrose substitute and can be applied as a low-calorie sweetener for obese patients or diabetics. Despite the enormous demand for D-psicose, its application has been seriously limited because D-psicose rarely exists in nature, and cannot be easily produced by chemical methods. Currently, the most common synthesis method involves a biological conversion catalyzed by D-psicose 3-epimerase (DPEase) or D-tagatose 3-epimerase (DTEase) (Scheme 1) [3]. Of the two enzymes, DTEase exhibits high activity towards D-tagatose, whereas the optimum substrate of DPEase is D-fructose.<smiles>O=C(CO)C(O)C(O)C(O)C(O)C(O)C(O)C(O)C(O)C(O)C(=O)CO</smiles>

Scheme 1. D-psicose production catalyzed by DPEase or DTEase. 
Immobilization can dramatically enhance the catalytic efficiency and the stability of enzymes. It can also reduce the production cost by enhancing the enzyme reusability [4-10]. For example, a DTEase has been successfully immobilized on Chitopearl beads BCW 2510 by ionic binding for the mass production of D-psicose from D-fructose [11]. Oh has immobilized DPEase from Agrobacterium tumefaciens (agtu-DPEase) on Duolite A568 beads for the production of D-psicose, with this immobilized D-psicose 3-epimerase exhibiting high productivity in the presence of borate [12]. The agtu-DPEase immobilized on graphene oxide particles has also been reported to have higher bioconversion efficiency than the free enzyme [13]. However, the enzyme activity in these studies reduces after immobilization, and their immobilization processes are complicated. A facile biomineralization approach was developed for enzyme immobilization by Zare et al. in 2012 [14]. They prepared a flower-like nanobiocatalyst by coordinating copper phosphate nanocrystals with laccase (a type of $\mathrm{Cu}^{2+}$-dependent enzyme). Its average size is about $3.0 \mu \mathrm{m}$, with a considerable number of separated petals produced in the nanometer range. The physical appearance of this resembles flowers in nature, and thus, it has been named 'nanoflower'. The immobilized laccase exhibited enzyme activity that was higher by approximately 6.5-fold compared to free laccase. This enzyme immobilization was performed under mild conditions and requires no toxic compounds. Using a similar method, Wang et al. [15] has fabricated a nanoflower by employing calcium phosphate crystals and $\alpha$-amylase. The new immobilized $\alpha$-amylase exhibited higher enzyme activity and stability than free $\alpha$-amylase and $\mathrm{Ca}^{2+}$. In the formation of nanoflowers, $\mathrm{Ca}^{2+}$ is located close to the enzyme, which can activate the Ca-dependent $\alpha$-amylase due to the allosteric phenomena. Moreover, the existence of the inorganic component in a nanoflower can dramatically enhance its mechanical stability, even under low power ultrasounds [16].

DPEase is a strictly metal-dependent enzyme. Cobalt (II) ion plays a pivotal role in catalysis by anchoring the substrate, and can help maximize the activity of DPEase by its allosteric effect [17]. To the best of our knowledge, employing biomimetic mineralization to immobilize DPEase has not yet been reported. In this study, we proposed a smart biomineralization method for creating hybrid organic-inorganic nanoflowers using a $\mathrm{Co}^{2+}$-dependent enzyme (DPEase) as the organic component and cobalt phosphate as the inorganic component. After the characterization of the as-prepared immobilized DPEase by scanning electron microscope (SEM) and fourier transform infrared (FTIR) spectroscopy, the catalytic properties of the prepared nanoflower have also been investigated to evaluate the immobilization.

\section{Results and Discussion}

\subsection{Morphology of Nanoflower}

The prepared nanoflower was characterized by SEM. Figure 1A depicts a typical image of the prepared nanoflower with the diameter of about $7 \mu \mathrm{m}$, which was constructed with a considerable number of nanosheets (with a size of about $200 \mathrm{~nm}$ ). The hierarchical structure with a high surface-to-volume ratio can improve the catalytic performance of the immobilized enzyme. The EDAX (Energy Dispersive X-ray Analysis, Figure 1B) verified the existence of cobalt and phosphorus in the prepared nanoflowers. A possible mechanism of nanoflower formation, which was based on coordination, in-situ precipitation, and finally assembly was proposed, and is illustrated in Figure 1C. 

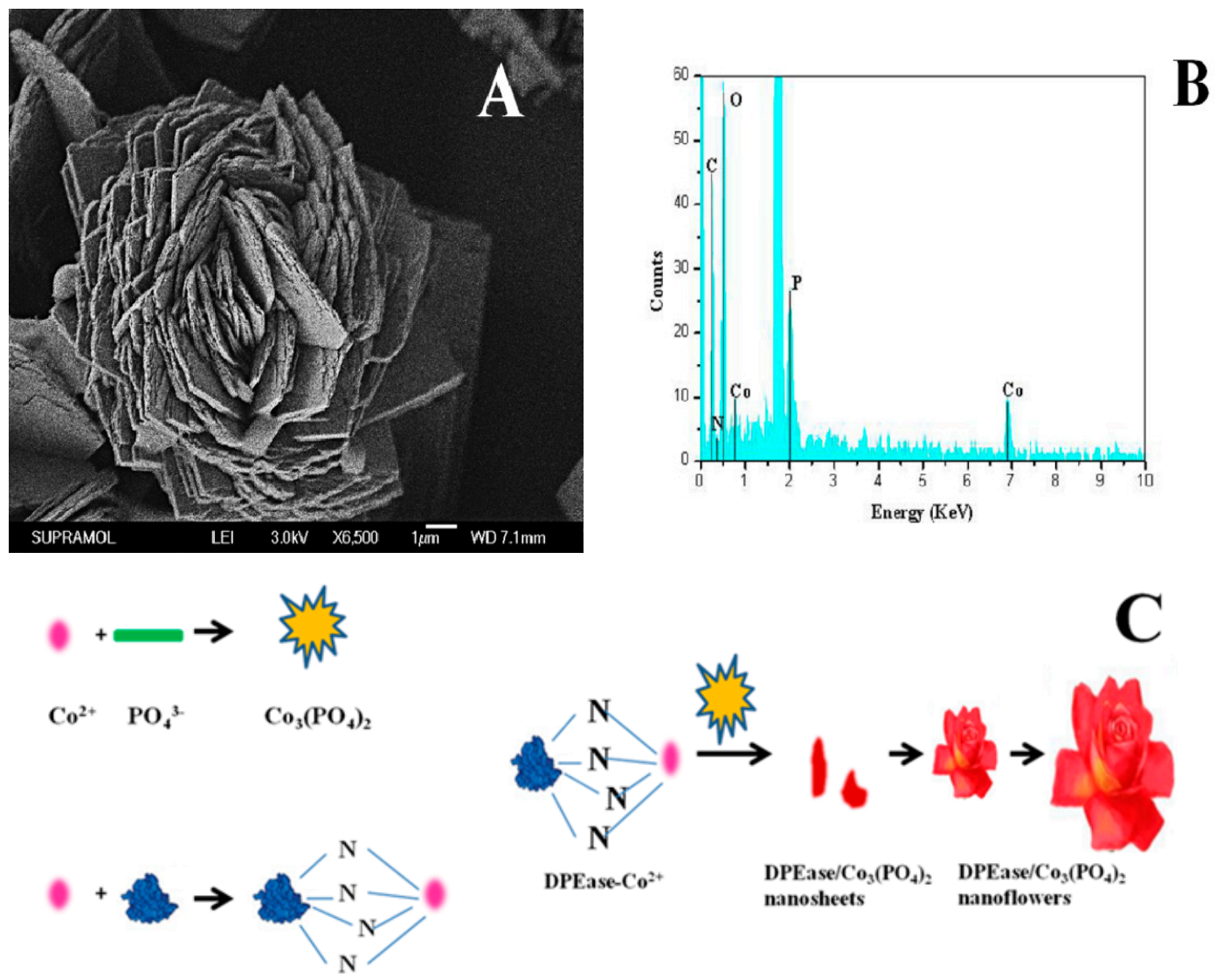

$\mathrm{Co}^{2+}$ DPEase DPEase-Co ${ }^{2+}$
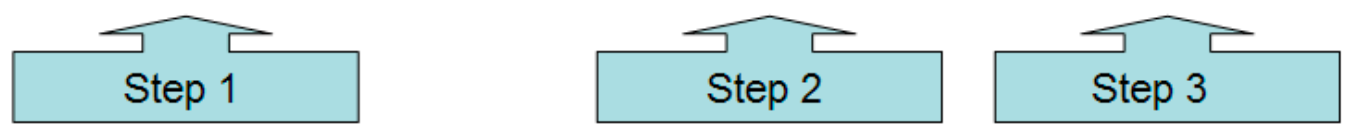

Figure 1. (A) Morphology of nanoflower; (B) EDAX analysis and (C) the possible mechanism of nanoflower formation.

The element contents were analyzed and are listed in Table 1. The $\mathrm{N}$ contents in DPEase, $\mathrm{Co}_{3}\left(\mathrm{PO}_{4}\right)_{2}$, and nanoflower were $7.102 \%, 0.007 \%$, and $0.880 \%$, respectively, which demonstrated that the $\mathrm{N}$ element in the immobilized sample was mainly from DPEase.

Table 1. Element analysis of nanoflower and its raw materials.

\begin{tabular}{cccc}
\hline Samples & C Element (\%) & H Element (\%) & N Element (\%) \\
\hline DPEase & 40.997 & 6.031 & 7.102 \\
$\mathrm{Co}_{3}\left(\mathrm{PO}_{4}\right)_{2}$ & 0.130 & 1.865 & 0.007 \\
Nanoflower & 3.154 & 2.095 & 0.880 \\
\hline
\end{tabular}

\subsection{FTIR of Nanoflowers}

The FTIR spectra of nanoflower (curve b), cobalt phosphate (curve a) and DPEase (curve c) are shown in Figure 2. The peaks at $1630 \mathrm{~cm}^{-1}$ and $1553 \mathrm{~cm}^{-1}$ are typical of amide I and II bands in the enzyme. The peaks at $1062 \mathrm{~cm}^{-1}$ and $975 \mathrm{~cm}^{-1}$ are the characteristic absorption peaks of $\mathrm{PO}_{4}{ }^{3-}$. All these major characteristic absorption peaks $[18,19]$ could be found in curve $b$, which confirmed the existence of the enzyme in the immobilized sample. 


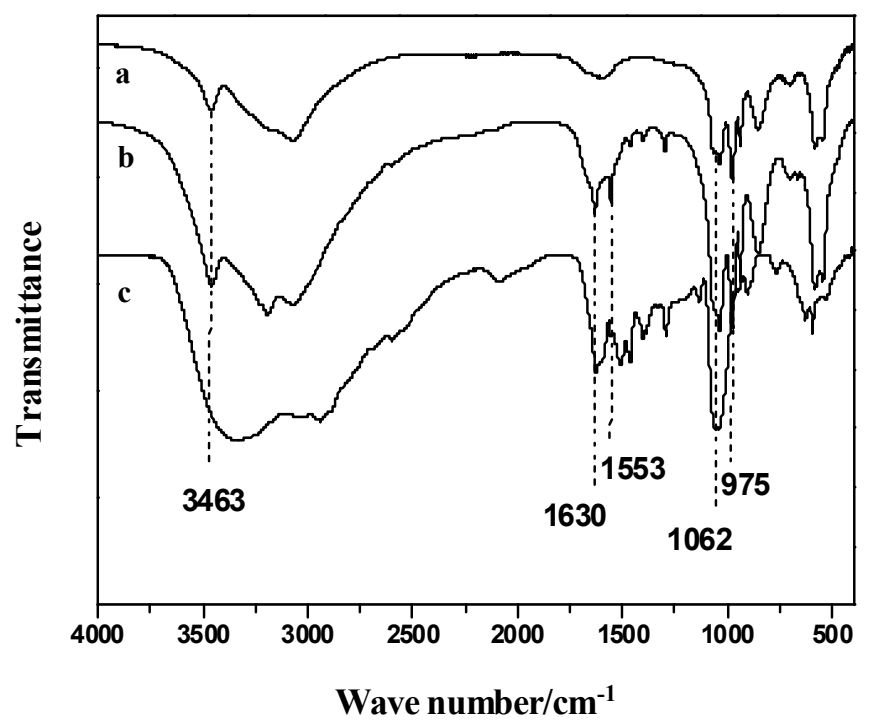

Figure 2. FTIR spectrum of the nanoflower (curve b) and its raw materials (curve a, cobalt phosphate; and curve c, DPEase).

\subsection{Comparison of Catalytic Properties of Nanoflower and Free DPEase}

\subsubsection{Effect of Temperature and Thermal Stability}

A high temperature can change the micro-environment of the enzyme and enhance the collision of enzyme and substrate, which will subsequently improve the enzyme activity [20-22]. Figure 3 presents the temperature profiles and the associated enzyme activity. For both the immobilized DPEase and free DPEase, the catalytic activity was enhanced with an increase in temperature until the highest value was reached at $60{ }^{\circ} \mathrm{C}$. After this, the catalytic activity decreased at a higher temperature due to the heat-induced denaturation of DPEase $[23,24]$. Furthermore, immobilization did not change its optimum temperature. However, almost $100 \%$ of enzyme activity for the nanoflower could be observed at $50-70{ }^{\circ} \mathrm{C}$, and the immobilized DPEase has significantly increased thermal stability compared to the free enzyme.

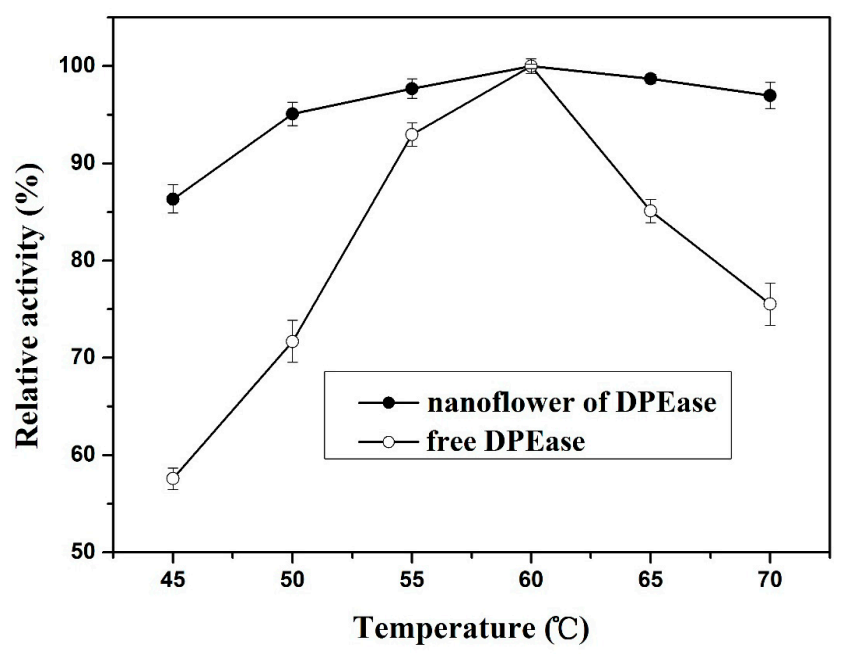

Figure 3. Effect of temperature on nanoflower and free DPEase. The enzyme activities of nanoflower $(36.2 \mathrm{U} / \mathrm{mg})$ and free DPEase $(5.0 \mathrm{U} / \mathrm{mg})$ at $60{ }^{\circ} \mathrm{C}$ were both $100 \%$.

Thermal stability is an important factor for any enzyme because a high temperature can speed up the bioconversion [25-28]. Our experimental results (Figure 4) demonstrated that the half-life of 
the nanoflower $\left(2 \mathrm{~h}\right.$ at $\left.60^{\circ} \mathrm{C}\right)$ is much longer than that of free DPEase $\left(20 \mathrm{~min}\right.$ at $\left.60^{\circ} \mathrm{C}\right)$. A similar phenomenon could be observed at $55^{\circ} \mathrm{C}$. These results highlighted that the prepared nanoflowers have excellent thermal stability.

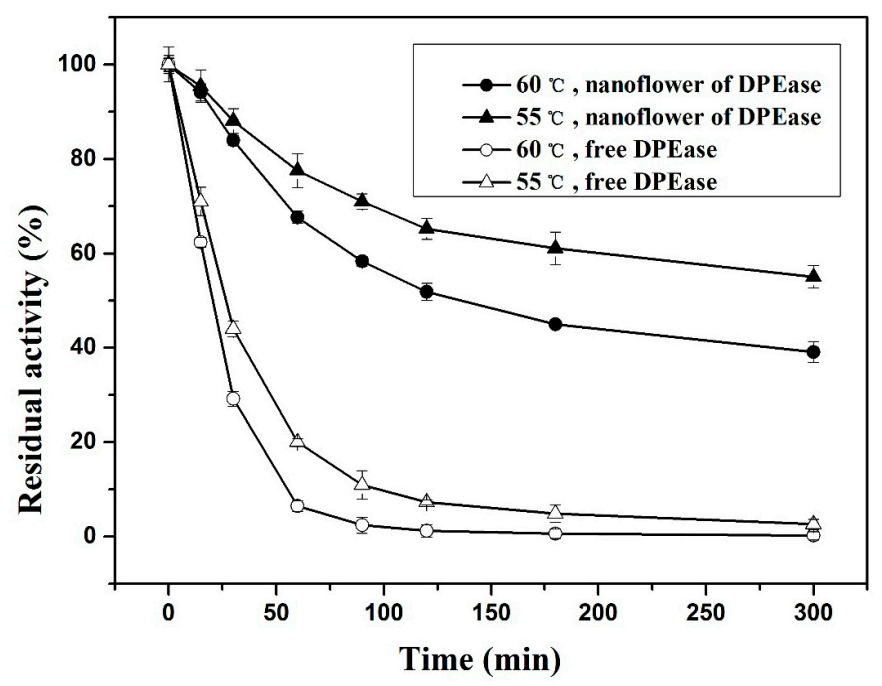

Figure 4. Thermal stability of nanoflower and free DPEase. The residual activities were determined at different given time intervals. The enzyme activities of the nanoflower $\left(36.2 \mathrm{U} / \mathrm{mg}\right.$ at $60{ }^{\circ} \mathrm{C}$ and $35.4 \mathrm{U} / \mathrm{mg}$ at $55^{\circ} \mathrm{C}$ ) and free DPEase $\left(5.0 \mathrm{U} / \mathrm{mg}\right.$ at $60^{\circ} \mathrm{C}$ and $4.6 \mathrm{U} / \mathrm{mg}$ at $\left.55^{\circ} \mathrm{C}\right)$ were both $100 \%$.

\subsubsection{Effect of $\mathrm{pH}$ and $\mathrm{pH}$ Stability}

The enzyme activities of the nanoflower and free DPEase at different $\mathrm{pH}$ values are shown in Figure 5. Our results demonstrated that the enzyme activities were sensitive to $\mathrm{pH}$ for both the free and immobilized DPEase. However, the immobilized enzyme has a significantly broader $\mathrm{pH}$ stability profile compared to the free enzyme. The optimum $\mathrm{pH}$ values were 8.0 and 8.5 , respectively. The mechanism of the optimum $\mathrm{pH}$ shift is unclear. Further investigation is currently being conducted and will be reported in the future.

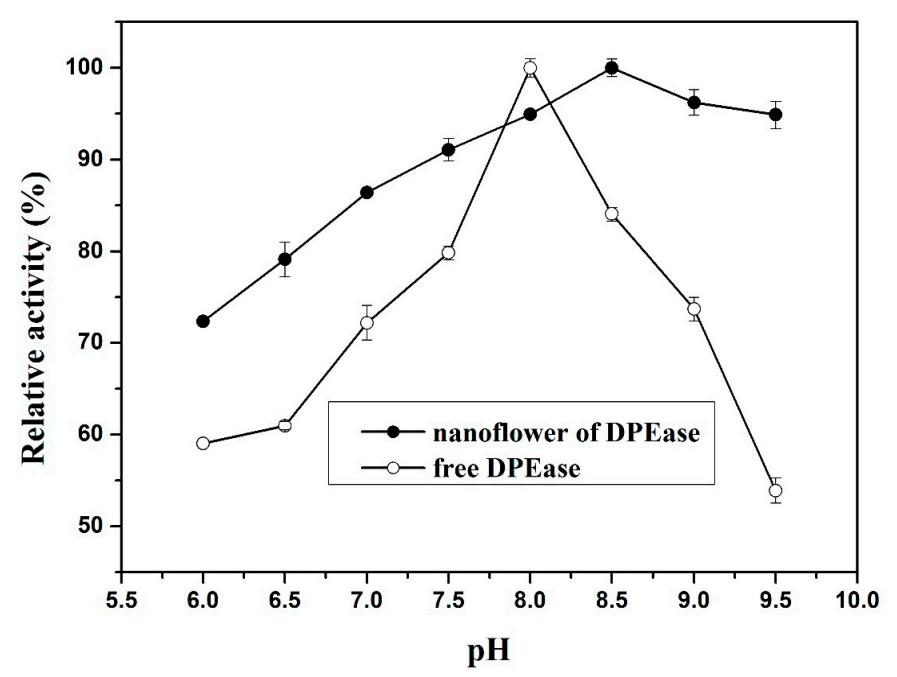

Figure 5. Effect of $\mathrm{pH}$ on nanoflower and free DPEase. The $\mathrm{pH}$ range was 6.0-9.5. The enzyme activities at a $\mathrm{pH}$ of 8.5 for nanoflower $(36.2 \mathrm{U} / \mathrm{mg})$ and at a $\mathrm{pH}$ of 8.0 for free DPEase $(5.0 \mathrm{U} / \mathrm{mg})$ were both $100 \%$.

$\mathrm{pH}$ stability was also a very important parameter for an immobilized enzyme [6,29,30]. In this study, we incubated both the free DPEase and nanoflower at different $\mathrm{pH}$ values for $2 \mathrm{~h}$, before 
measuring their residual activities. The results in Figure 6 indicated that the nanoflower was much more stable than free DPEase in the selected $\mathrm{pH}$ range, and that more than $90 \%$ of its enzyme activity was achieved at a $\mathrm{pH}$ of 7.0-9.5.

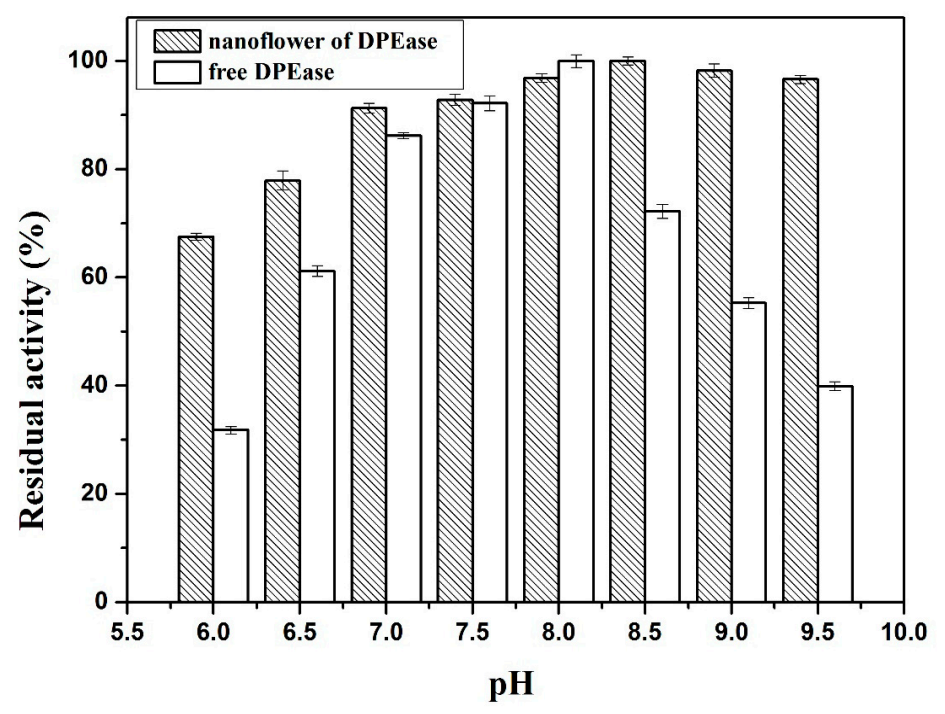

Figure 6. $\mathrm{pH}$ stability of nanoflower and free DPEase. Both the free DPEase and the nanoflower were pre-incubated at $4{ }^{\circ} \mathrm{C}$ and different $\mathrm{pH}$ values for $2.0 \mathrm{~h}$. After this, the residual activity was measured. The DPEase activities at a $\mathrm{pH}$ of 8.5 for nanoflower $(36.2 \mathrm{U} / \mathrm{mg})$ and at a $\mathrm{pH}$ of 8.0 for free DPEase (5.0 $\mathrm{U} / \mathrm{mg}$ ) were both $100 \%$, respectively.

\subsubsection{Free DPEase vs the Prepared Nanoflower}

The catalytic activities of free DPEase and nanoflower were compared under their own optimum conditions (Table 2). The DPEase activity was enhanced by approximately 7.2-fold after immobilization. DPEase is a strictly $\mathrm{Co}^{2+}$-dependent enzyme. In the formation of a nanoflower, $\mathrm{Co}^{2+}$ can bind to the specific functional sites of DPEase and activate DPEase by an allosteric effect. Furthermore, $\mathrm{Co}^{2+}$ and DPEase are squeezed in a limited space of the prepared nanoflower [31,32]. $\mathrm{Co}^{2+}$ is located very close to DPEase, and can activate DPEase easily and quickly. Thus, most DPEases in the active form might be enriched or locked during immobilization, which may be the main reason for the enhanced enzyme activity of the nanoflower. Furthermore, the prepared nanoflower has high surface-to-volume ratios, which can decrease the mass transfer limitations dramatically [33,34], and subsequently improve the enzyme performance.

Table 2. Comparison of enzyme activity of nanoflower and free DPEase.

\begin{tabular}{cc}
\hline Sample & Enzyme Activity (U/mg) \\
\hline Free DPEase $^{\mathrm{a}}$ & $5.0 \pm 0.2$ \\
Nanoflower $^{\mathrm{b}}$ & $36.2 \pm 0.5$
\end{tabular}

a: The assay mixture contained D-fructose $(500.0 \mathrm{mg} / \mathrm{mL}, 100.0 \mu \mathrm{L}), \mathrm{Co}^{2+}(10.0 \mathrm{mM}, 10.0 \mu \mathrm{L})$, free DPEase $(2.0 \mathrm{mg} / \mathrm{mL}, 10.0 \mu \mathrm{L})$ and Tris- $\mathrm{HCl}$ buffer $(50.0 \mathrm{mM}, \mathrm{pH} 8.0,880.0 \mu \mathrm{L})$. The reaction was performed at $60{ }^{\circ} \mathrm{C}$ for $10 \mathrm{~min} .{ }^{\mathrm{b}}$ : The assay mixture contained D-fructose $(500.0 \mathrm{mg} / \mathrm{mL}, 100.0 \mu \mathrm{L}), \mathrm{Co}^{2+}(10.0 \mathrm{mM}, 10.0 \mu \mathrm{L})$, nanoflower $(0.17 \mathrm{mg}$, containing $20.0 \mu \mathrm{g}$ of DPEase) and Tris-HCl buffer $(50.0 \mathrm{mM}, \mathrm{pH} 8.5,890.0 \mu \mathrm{L})$. The reaction was performed at $60^{\circ} \mathrm{C}$ for $10 \mathrm{~min}$.

\subsubsection{Reusability}

Reusability is one of the most advantageous factors of immobilized enzymes [35,36]. After each reaction cycle, nanoflowers were separated by centrifugation and washed three times for the next reaction batch. The DPEase-nanoflower still had $90 \%$ of its activity after six reaction cycles (Figure 7). 
The excellent reusability of the fabricated nanoflower might be attributed to its high thermal stability and reduced loss of DPEase during the continuous reaction batches.

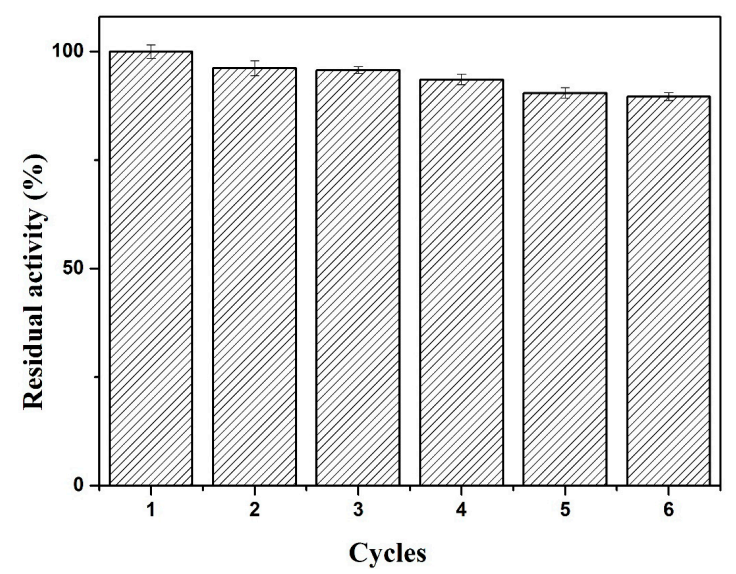

Figure 7. The reusability of the prepared DPEase nanoflower. The assay mixture contained D-fructose $(500.0 \mathrm{mg} / \mathrm{mL}, 100.0 \mu \mathrm{L}), \mathrm{Co}^{2+}(10.0 \mathrm{mM}, 10.0 \mu \mathrm{L})$, nanoflower $(0.17 \mathrm{mg}$, containing $20.0 \mu \mathrm{g}$ of DPEase $)$ and Tris- $\mathrm{HCl}$ buffer $(50.0 \mathrm{mM}, \mathrm{pH} 8.5,890.0 \mu \mathrm{L})$. The reaction was performed at $60{ }^{\circ} \mathrm{C}$ for $10 \mathrm{~min}$. After each reaction cycle, the nanoflower was recycled by centrifugation and reused for the next run.

\section{Materials and Methods}

\subsection{Materials}

D-psicose 3-epimerase (DPEase, protein purity, 90\%) was donated from China Oil \& Foodstuffs Corporation (COFCO, Beijing, China). The DPEase encoded by the gene Ccel_0941 from Clostridium cellulolyticum H10 (ATCC 35319) was cloned and expressed in Escherichia coli [37]. This is strictly a $\mathrm{Co}^{2+}$-dependent enzyme (enzyme activity, $5.0 \mathrm{U} / \mathrm{mg}$ at $60^{\circ} \mathrm{C} ; \mathrm{Km}=18.35 \mathrm{mM}$ ). $\mathrm{KBr}$ and other reagents were from Aladdin Chem-reagent Co. (Aladdin, Shanghai, China).

\subsection{Preparation of the Nanoflowers}

DPEase $(2.0 \mathrm{mg})$ was added to the phosphate buffer $(\mathrm{pH} 7.4,50.0 \mathrm{mM}, 2.0 \mathrm{~mL})$. A solution of $\mathrm{CoSO}_{4}(1.0 \mathrm{M}, 10.0 \mu \mathrm{L})$ was dissolved in the above solution at $4{ }^{\circ} \mathrm{C}$ under magnetic stirring (about $150 \mathrm{rpm}$ ) and incubated for $48 \mathrm{~h}$. The sediments collected by centrifugation (5000 rpm, $6 \mathrm{~min}$ ) were washed by ultrapure water ( 3 times) and dried under a vacuum. The recovered nanoflower was $12.4 \mathrm{mg}$. Its protein content (12\%) was detected by the Bradford protein assay kit (Bio-Rad Laboratories, Hercules, CA, USA) [38,39].

\subsection{Characterization of the Prepared Nanoflowers}

The morphology was recorded by JSM-6700F electron microscope (JEOL, Tokyo, Japan). Element content was detected by Elementar Vario MACRO cube (Elementar Analysensysteme GmbH, Langenselbold, Germany). Nicolet 5700 FTIR spectrometer (Thermo, Madison, WI, USA) was used to detect the FTIR spectrum of samples.

\subsection{Standard Enzyme Activity Assay}

The assay mixture contained D-fructose $(500.0 \mathrm{mg} / \mathrm{mL}, 100.0 \mu \mathrm{L}), \mathrm{Co}^{2+}(10.0 \mathrm{mM}, 10.0 \mu \mathrm{L})$ and Tris- $\mathrm{HCl}$ buffer $(50.0 \mathrm{mM}, \mathrm{pH} 8.0,880.0 \mu \mathrm{L})$. DPEase $(2.0 \mathrm{mg} / \mathrm{ml}, 10.0 \mu \mathrm{L})$ was added to start the reaction at $60^{\circ} \mathrm{C}$ for $10 \mathrm{~min}$. For the nanoflower, the assay mixture contained D-fructose $(500.0 \mathrm{mg} / \mathrm{mL}$, $100.0 \mu \mathrm{L}), \mathrm{Co}^{2+}(10.0 \mathrm{mM}, 10.0 \mu \mathrm{L})$, nanoflower $(0.17 \mathrm{mg}$, containing $20.0 \mu \mathrm{g}$ DPEase $)$ and Tris- $\mathrm{HCl}$ buffer $(50.0 \mathrm{mM}, \mathrm{pH} 8.5,890.0 \mu \mathrm{L})$. The reaction was performed at $60{ }^{\circ} \mathrm{C}$ for $10 \mathrm{~min}$. HPLC was used to determine the produced D-psicose. The DPEase activity $(\mathrm{U})$ was determined by the DPEase 
dosage required to release $1.0 \mu \mathrm{mol}$ of D-psicose per min at $60^{\circ} \mathrm{C}$. The experiments were performed in triplicate, with the mean of the three experiments used for this present study.

\subsection{HPLC Analysis}

The produced D-psicose was monitored on Agilent 1260 HPLC (Agilent, Santa Clara, CA, USA) by a refractive index detector at $80^{\circ} \mathrm{C}$. The injection volume was $20 \mu \mathrm{L}$. A Waters Sugar-Pak I Column $(10.0 \mu \mathrm{m}, 6.5 \mathrm{~mm} \times 300.0 \mathrm{~mm})$ was equipped for the analysis, with deionized water used as the mobile phase $(0.4 \mathrm{~mL} / \mathrm{min})$. The retention times of D-fructose and D-psicose were $15.017 \mathrm{~min}$ and $21.995 \mathrm{~min}$, respectively (see Supplementary Materials Figure S1).

\section{6. $p H$ Stability}

The $\mathrm{pH}$ stability was determined in the $\mathrm{pH}$ range of 6.0-9.5. Both the free DPEase and the nanoflower were pre-incubated at $4{ }^{\circ} \mathrm{C}$ and different $\mathrm{pH}$ values for $2.0 \mathrm{~h}$. After this, the residual activity was measured according to the standard assay as described in Section 3.4.

\subsection{Thermal Stability}

The thermal stability was investigated by exposing the enzyme at different temperatures $\left(55^{\circ} \mathrm{C}\right.$ and $60^{\circ} \mathrm{C}$ ) for different time intervals. The residual activity was measured at the given time intervals according to the standard assay as described in Section 3.4.

\subsection{Reusability}

To investigate the reusability of the nanoflower, a batch reaction was performed under the optimized reaction conditions for $10 \mathrm{~min}$. After this, the nanoflower separated by centrifugation (5000 rpm, $6 \mathrm{~min}$ ) was washed by ultrapure water ( 3 times) and dried under a vacuum. The leaching of DPEase was monitored by the Bradford protein assay, and no protein could be detected. The recycled nanoflower was reused for the next run.

\section{Conclusions}

In summary, a smart biomineralization method was reported for the immobilization of a $\mathrm{Co}^{2+}$-dependent enzyme (DPEase). This novel method can dramatically activate the $\mathrm{Co}^{2+}$-dependent DPEase during the immobilization, and greatly enhance the enzyme stability. This new biomineralization method is favorable for the immobilization of metal-dependent enzymes for important applications in biosensors, bioanalytical devices, and industrial biocatalysis.

Supplementary Materials: The supplementary materials are available at http:/ / www.mdpi.com/2073-4344/8/ $10 / 468 /$ s1.

Author Contributions: L.Z. contributed to enzyme assay and wrote the paper, Y.S. contributed to FTIR spectrum and XRD spectrum, J.W. contributed to HPLC, H.H. and X.G. analyzed the data, Y.T. and Z.W. conceived and designed the experiments.

Funding: This research was funded by the Special Project for Health from Jilin Province (No. 2018SCZWSZX-037).

Conflicts of Interest: The authors declare no conflict of interest.

\section{References}

1. Chattopadhyay, S.; Raychaudhuri, U.; Chakraborty, R. Artificial Sweeteners-A Review. J. Food Sci. Tech. 2014, 51, 611-621. [CrossRef] [PubMed]

2. Tsukamoto, I.; Hossain, A.; Yamaguchi, F.; Hirata, Y.; Dong, Y.; Kamitori, K.; Sui, L.; Machiko, N.; Masaki, U.; Kazuyuki, N.; et al. Intestinal Absorption, Organ Distribution, and Urinary Excretion of the Rare Sugar D-psicose. Drug Des. Dev. Ther. 2014, 8, 1955-1964.

3. Mu, W.; Zhang, W.; Feng, Y.; Jiang, B.; Zhou, L. Recent advances on applications and biotechnological production of D-psicose. Appl. Microbiol. Biot. 2012, 94, 1461-1467. [CrossRef] [PubMed] 
4. Fernández-Lafuente, R.; Rodrı́guez, V.; Mateo, C.; Penzol, G.; Hernández-Justiz, O.; Irazoqui, G.; Villarino, A.; Ovsejevi, K.; Batista, F.; Guisán, J.M. Stabilization of Multimeric Enzymes via Immobilization and Post-immobilization Techniques. J. Mol. Catal. B Enzym. 1999, 7, 181-189. [CrossRef]

5. Palomo, J.M.; Muñoz, G.; Fernández-Lorente, G.; Mateo, C.; Fernández-Lafuente, R.; Guisán, J.M. Interfacial Adsorption of Lipases on Very Hydrophobic Support (octadecyl-Sepabeads): Immobilization, Hyperactivation and Stabilization of the Open Form of Lipases. J. Mol. Catal. B Enzym. 2002, 19, $279-286$. [CrossRef]

6. Mateo, C.; Palomo, J.M.; Fernandez-Lorente, G.; Guisan, J.M.; Fernandez-Lafuente, R. Improvement of Enzyme Activity, Stability and Selectivity via Immobilization Techniques. Enzyme Microb. Technol. 2007, 40, 1451-1463. [CrossRef]

7. Fernández-Lorente, G.; Palomo, J.M.; Cabrera, Z.; Guisán, J.M.; Fernández-Lafuente, R. Specificity Enhancement towards Hydrophobic Substrates by Immobilization of Lipases by Interfacial Activation on Hydrophobic Supports. Enzyme Microb. Technol. 2007, 41, 565-569. [CrossRef]

8. Fernández-Lorente, G.; Cabrera, Z.; Godoy, C.; Fernandez-Lafuente, R.; Palomo, J.M.; Guisan, J.M. Interfacially Activated Lipases against Hydrophobic Supports: Effect of the Support Nature on the Biocatalytic Properties. Process Biochem. 2008, 43, 1061-1067. [CrossRef]

9. Suescun, A.; Rueda, N.; dos Santos, J.C.; Castillo, J.J.; Ortiz, C.; Torres, R.; Barbosa, O.; Fernandez-Lafuente, R. Immobilization of Lipases on Glyoxyl-octyl Supports: Improved Stability and Reactivation Strategies. Process Biochem. 2015, 50, 1211-1217. [CrossRef]

10. Wilson, L.; Palomo, J.M.; Fernández-Lorente, G.; Illanes, A.; Guisán, J.M.; Fernández-Lafuente, R. Improvement of the Functional Properties of a Thermostable Lipase from Alcaligenes sp. via Strong Adsorption on Hydrophobic Supports. Enzyme Microb. Technol. 2006, 38, 975-980. [CrossRef]

11. Takeshita, K.; Suga, A.; Takada, G.; Izumori, K. Mass Production of D-psicose from D-fructose by a Continuous Bioreactor System Using Immobilized D-Tagatose 3-Epimerase. J. Biosci. Bioeng. 2000, 90, 453-455. [CrossRef]

12. Lim, B.C.; Kim, H.J.; Oh, D.K. A Stable Immobilized D-Psicose 3-Epimerase for the Production of D-Psicose in the Presence of Borate. Process Biochem. 2009, 44, 822-828. [CrossRef]

13. Dedania, S.R.; Patel, M.J.; Patel, D.J.; Patel, D.M.; Akhani, R.C.; Patel, D.H. Immobilization on Graphene Oxide Improves the Thermal Stability and Bioconversion Efficiency of D-Psicose 3-Epimerase for Rare Sugar Production. Enzyme Microb. Technol. 2017, 107, 49-56. [CrossRef] [PubMed]

14. Ge, J.; Lei, J.; Zare, R.N. Protein-inorganic Hybrid Nanoflowers. Nat. Nanotechnol. 2012, 7, 428-432. [CrossRef] [PubMed]

15. Wang, L.; Wang, Y.; He, R.; Zhuang, A.; Wang, X.; Zeng, J.; Hou, J.G. A New Nanobiocatalytic System Based on Allosteric Effect with Dramatically Enhanced Enzymatic Performance. J. Am. Chem. Soc. 2013, 135, 1272-1275. [CrossRef] [PubMed]

16. An, B.; Fan, H.; Wu, Z.; Zheng, L.; Wang, L.; Wang, Z.; Chen, G. Ultrasound-assisted enantioselective esterification of ibuprofen catalyzed by a flower-like nanobioreactor. Molecules 2016, 21, 565. [CrossRef] [PubMed]

17. Kim, K.; Kim, H.J.; Oh, D.K.; Cha, S.S.; Rhee, S. Crystal Structure of D-psicose 3-epimerase from Agrobacterium Tumefaciens and Its Complex with True Substrate D-fructose: A Pivotal Role of Metal in Catalysis, an Active Site for the Non-phosphorylated Substrate, and Its Conformational Changes. J. Mol. Biol. 2006, 361, 920-931. [CrossRef] [PubMed]

18. Kim, K.H.; Jeong, J.M.; Lee, S.J.; Choi, B.G.; Lee, K.G. Protein-directed Assembly of Cobalt Phosphate Hybrid Nanoflowers. J. Colloid Interf. Sci. 2016, 484, 44-50. [CrossRef] [PubMed]

19. Song, Y.; Gao, J.; He, Y.; Zhou, L.; Ma, L.; Huang, Z.; Jiang, Y. Preparation of a Flowerlike Nanobiocatalyst System via Biomimetic Mineralization of Cobalt Phosphate with Enzyme. Ind. Eng. Chem. Res. 2017, 56, 14923-14930. [CrossRef]

20. Cornishbowden, A. Enthalpy-entropy Compensation and the Isokinetic Temperature in Enzyme Catalysis. J. Biosci. 2017, 42, 665-670. [CrossRef]

21. Daniel, R.M.; Danson, M.J.; Eisenthal, R.; Lee, C.K.; Peterson, M.E. The Effect of Temperature on Enzyme Activity: New Insights and Their Implications. Extremophiles 2008, 12, 51-59. [CrossRef] [PubMed] 
22. Daniel, R.M.; Peterson, M.E.; Danson, M.J.; Price, N.C.; Kelly, S.M.; Monk, C.R.; Weinberg, C.S.; Oudshoorn, M.L.; Lee, C.K. The Molecular Basis of the Effect of Temperature on Enzyme Activity. Biochem. J. 2010, 425, 353-360. [CrossRef] [PubMed]

23. Matsuura, S.I.; Chiba, M.; Tsunoda, T.; Aritomo, Y. Enzyme Immobilization in Mesoporous Silica for Enhancement of Thermostability. J. Nanosci. Nanotechno. 2018, 18, 104-109. [CrossRef] [PubMed]

24. Yu, D.; Tian, L.; Ma, D.; Wu, H.; Wang, Z.; Wang, L.; Fang, X. Microwave-assisted Fatty Acid Methyl Ester Production from Soybean Oil by Novozym 435. Green Chem. 2010, 12, 844-850. [CrossRef]

25. Da Silva, T.M.; Maller, A.; de Lima Damásio, A.R.; Michelin, M.; Ward, R.J.; Hirata, I.Y.; Jorge, J.A.; Terenzi, H.F.; de Polizeli, M.L.T.M. Properties of a Purified Thermostable Glucoamylase from Aspergillus Niveus. J. Ind. Microbiol. Biot. 2009, 36, 1439-1446. [CrossRef] [PubMed]

26. Zamost, B.L.; Nielsen, H.K.; Starnes, R.L. Thermostable Enzymes for Industrial Applications. J. Ind. Microbiol. Biot. 1991, 8, 71-81. [CrossRef]

27. Yang, C.-H.; Huang, Y.-C.; Chen, C.-Y.; Wen, C.-Y. Heterologous Expression of Thermobifida Fusca, Thermostable Alpha-amylase in Yarrowia Lipolytica, and its Application in Boiling Stable Resistant Sago Starch Preparation. J. Ind. Microbiol. Biot. 2010, 37, 953-960. [CrossRef] [PubMed]

28. Galante, Y.M.; Formantici, C. Enzyme Applications in Detergency and in Manufacturing Industries. Curr. Org. Chem. 2003, 7, 1399-1422. [CrossRef]

29. Mohamad, N.R.; Marzuki, N.H.C.; Buang, N.A.; Huyop, F.; Wahab, R.A. An Overview of Technologies for Immobilization of Enzymes and Surface Analysis Techniques for Immobilized Enzymes. Biotechnol. Biotechnol. Equip. 2015, 29, 205-220. [CrossRef] [PubMed]

30. Rueda, N.; dos Santos, J.C.S; Ortiz, C.; Torres, R.; Barbosa, O.; Rodrigus, R.C.; Berengure-Murcia, Á.; Fernandez-Lafuente, R. Chemical Modification in the Design of Immobilized Enzyme Biocatalysts: Drawbacks and Opportunities. Chem. Rec. 2016, 16, 1436-1455. [CrossRef] [PubMed]

31. Minton, A.P. The Influence of Macromolecular Crowding and Macromolecular Confinement on Biochemical Reactions in Physiological Media. J. Biol. Chem. 2001, 276, 10577-10580. [CrossRef] [PubMed]

32. Zhou, H.X.; Dill, K.A. Stabilization of Proteins in Confined Spaces. Biochemistry 2001, 40, 11289-11293. [CrossRef]

33. Zheng, L.; Xie, X.; Wang, Z.; Zhang, Y.; Wang, L.; Cui, X.; Huang, H.; Zhuang, H. Fabrication of a Nano-biocatalyst for Regioselective Acylation of Arbutin. Green Chem. Lett. Rev. 2018, 11, 55-61. [CrossRef]

34. Wu, Z.; Li, X.; Li, F.; Yue, H.; He, C.; Xie, F.; Wang, Z. Enantioselective Transesterification of (R,S)-2-pentanol Catalyzed by a New Flower-like Nanobioreactor. RSC Adv. 2014, 4, 33998-34002. [CrossRef]

35. Mehta, J.; Bhardwaj, N.; Bhardwaj, S.K.; Kim, K.H.; Deep, A. Recent Advances in Enzyme Immobilization Techniques: Metal-organic Frameworks as Novel Substrates. Coordin. Chem. Rev. 2016, 322, 30-40. [CrossRef]

36. Yang, Q.; Wang, B.; Zhang, Z.; Lou, D.; Tan, J.; Zhu, L. The Effects of Macromolecular Crowding and Surface Charge on the Properties of an Immobilized Enzyme: Activity, Thermal Stability, Catalytic Efficiency and Reusability. RSC Adv. 2017, 7, 38028-38036. [CrossRef]

37. Mu, W.; Chu, F.; Xing, Q.; Yu, S.; Zhou, L.; Jiang, B. Cloning, Expression, and Characterization of a D-psicose 3-epimerase from Clostridium Cellulolyticum H10. J. Agric. Food Chem. 2011, 59, 7785-7792. [CrossRef] [PubMed]

38. Bradford, M.M. A rapid and Sensitive Method for the Quantitation of Microgram Quantities of Protein Utilizing the Principle of Protein-dye Binding. Anal. Biochem. 1976, 72, 248-254. [CrossRef]

39. Liese, A.; Hilterhaus, L. Evaluation of Immobilized Enzymes for Industrial Applications. Chem. Soc. Rev. 2013, 42, 6236-6249. [CrossRef] [PubMed]

(C) 2018 by the authors. Licensee MDPI, Basel, Switzerland. This article is an open access article distributed under the terms and conditions of the Creative Commons Attribution (CC BY) license (http:/ / creativecommons.org/licenses/by/4.0/). 